Журнал«Герспективитаінноваціїнаукиљ

(Серія«Гедагогіка», Серія«ГТихологія», Серія«Медицинв»

№2(7) 2022

УДК 159.9

https://doi.org/10.52058/2786-4952-2022-2(7)-900-913

Надьон Вікторія Петрівна аспірант кафедри психології, Харківський національний педагогічний університет імені Г.С. Сковороди, вул. Алчевських, 29, м. Харків, 61002, тел.: (096) 283-63-67, https://orcid.org/0000-0003-1939-1980

\title{
ОСОБИСТІСНІ ВЛАСТИВОСТІ МОЛОДШОГО ШКОЛЯРА В ЗАЛЕЖНОСТІ ВІД ГУБРИСТИЧНОЇ МОТИВАЦІЇ ТА РІВНЯ ДОМАГАНЬ
}

Анотація. Дослідження губристичних мотивів молодших школярів $є$ новим напрямком наукових розвідок, тому дослідження особливостей самосвідомості та особистісних рис молодших школярів в залежності від їх домінуючої губристичної мотивації $\epsilon$ актуальним, а розгляд особистісного розвитку під впливом губристичної мотивації та рівня домагань визначило мету даного дослідження.

У результаті впровадження кластерного аналізу методом К-середніх було отримано 5 кластерних профілів губристичної мотивації молодших школярів: «Помірне домінування прагнення до переваги», «Збалансовані губристичні мотиви», «Домінування прагнення до переваги», «Низький рівень губристичної мотивації», «Домінування прагнення до досконалості».

Емпірично виявлено, що за схильністю до володіння матеріальними цінностями та бажанням переваги молодші школярів із «Домінуванням прагнення до досконалості» поступаються іншим школярам, утім вони переважають інших за показниками агресії як захисту. Ознаки домінантності більшою мірою властиві школярам із «Помірним домінуванням прагнення до переваги», а учнів із «Низьким рівнем губристичних мотивів» мають найнижчий рівень спрямованості на домінування над іншими. Афіліативне прагнення бути добрим другом і належати виражене найменше, натомість заздрість проявляється більшою мірою в учнів із «Низьким рівнем губристичної мотивації». Тривожність більшою мірою характеризує молодших школярів із «Домінуванням прагнення до переваги». Фігура матері як значуща та загальна прив'язаність до матері є більш вираженими у досліджуваних із «Низьким рівнем губристичної мотивації». Сексуальна стурбованість та самооцінка більшою мірою виражені у школярів із «Збалансованими губристичними мотивами». Моральність меншою мірою, а потреба у захисті та у прив'язаності - більшою мірою характеризує молодших школярів із «Домінуванням прагнення до переваги».

Виявлено рівномірну представленість молодших школярів 3 рівнем домагань - завищеним, заниженим, адекватним та інфантильним. Статистично значущі відмінності для учнів 3 різним рівнем домагань виявлено за 
параметрами агресії типу А, потреби в афіліації та захисті, значущості фігур матері та батька, а також самооцінки.

Тип губристичної мотивації разом з рівнем домагань позначаються на рівні розвитку амбівалентності, домінування, агресії типу А, агресії як помсти, значущості фігури батька, бажання переваги, сексуальної стурбованості та моральності у молодших школярів.

Ключові слова: губристична мотивація, прагнення до переваги, прагнення до досконалості, рівень домагань, особистість молодшого школяра.

Nadyon Victoria Petivna Postgraduate student of the Department of Psychology, H.S. Skovoroda Kharkiv National Pedagogical University, Alchevskikh St., 29, Kharkiv, 61002, tel.: (096) 283-63-67, https://orcid.org/0000-0003-1939-1980

\section{PERSONAL PROPERTIES OF A JUNIOR SCHOOLCHILDREN DEPENDING ON HUBRISTIC MOTIVATION AND LEVEL OF ASPIRATIONS}

Abstract. The study of the hubristic motives of junior schoolchildren is a new direction of scientific exploration, so the study of the features of self-consciousness and personal rice of junior schoolchildren, depending on their dominant hubristic motivation, is relevant, and consideration of personal development under the influence of hubristic motivation and level of aspirations has determined the purpose of this study.

As a result of the cluster analysis 5 cluster profiles of the gauge motivation of junior schoolchildren were obtained: "Moderate domination of the desire for superiority", "Balanced hubristic motives", "Domination of the pursuit of superiority", "Low hubristic Motivation", "Domination of the desire to perfection". Empirically revealed that according to a tendency to possession of material values and the desire of the benefits of younger schoolchildren with "Domination of the desire for superiority " inferior to other schoolchildren, they are more dominated by others in the indicators of aggression as protection. Signs of dominance are more inherent in schoolchildren with "moderate dominance of the desire for advantage", and students with "low levels of hubristic motives" have the lowest level of direction for domination over others. The affiliative desire to be a good friend and belong to the least, instead, envy is manifested to a greater extent in students with a "Low level of hubristic motivation." Anxiety is more characterized by junior schoolchildren with " Domination of the pursuit of superiority". Mother figure as a significant and general adhesion to the mother are more pronounced in the investigated with "low level of hubristic motivation". Sexual concern and self-esteem are more pronounced in schoolchildren with "Balanced hubristic motives". Morality to a lesser extent, and the need for protection and attachment - to a greater extent characterizing younger schoolchildren with "Domination of the pursuit of superiority ". The uniform representation of junior schoolchildren with the level of claims is revealed - inflated, 
underestimated, adequate and infantile. Statistically significant differences for students with different levels of aspirations were found according to the parameters of the type A, the need for affiliation and protection, the significance of mother and father's figures, as well as self-esteem.

The type of hubristic motivation together with the level of aspirations is indicated at the level of development of ambivalence, domination, aggression of type A, aggression as revenge, significance of the Father's figure, the desire of advantage, sexual concerns and morality in younger schoolchildren.

Key words: hubristic motivation, striving for superiority, aspiration for perfection, level of aspiration, personality of a junior pupil.

Постановка проблеми. Вивчення губристичних мотивів молодших школярів $\epsilon$ новим напрямком наукових розвідок, тому дослідження особливостей самосвідомості та особистісних рис молодших школярів в залежності від їх домінуючої губристичної мотивації є актуальним, а розгляд особистісного розвитку під впливом губристичної мотивації та рівня домагань визначило мету даного дослідження.

Аналіз останніх досліджень і публікацій. Важливі аспекти формування та розвитку особистості молодшого школяра у зв'язку із губристичною мотивацією представлені у роботах Н.Ю. Діомідової, К.І. Фоменко, О. Шукалової, О. Щербакової. Утім проблема синегрвї факторів губристичної мотивації та рівня домагань у розвитку особистості молодшого школяра $є$ новою.

Мета статті - дослідження особистісних особливостей молодших школярів в залежності від рівня домагань та типу губристичної мотивації.

\section{Виклад основного матеріалу.}

1. Проєктивна методика «Казкове царство» [3] для старшого дошкільного та молодшого шкільного віку була розроблена нами 3 метою вивчення губристичної мотивації у дітей у віці 6-10 років. Методика дозволяє визначити міру вираженості прагнення до переваги та прагнення до досконалості у дітей. Процедура дослідження передбачала вибір молодшим школярів однієї із вісімнадцяти карток із казковими персонажами.

Кожному 3 персонажів відповідає певна кількість балів за шкалами прагнення до переваги та прагнення до досконалості, а саме:

1) Картки верхнього щабля (Цар і Цариця) - 3 бали за шкалою прагнення до переваги та 0 балів за шкалою прагнення до досконалості;

2) Картки середнього щаблю, а саме: Царівна-Прекрасна та ЦаревичШляхетний - 2 бали за шкалою прагнення до переваги і 0 балів за шкалою прагнення до досконалості;

3) Картки середнього щаблю, а саме: Царівна-Майстриня і ЦаревичУмілий - 2 бали за шкалою прагнення до переваги та 2 бали за шкалою прагнення до досконалості;

4) Картки середнього щаблю, а саме: Царівна-Премудра і ЦаревичМолодецький - 2 бали за шкалою прагнення до переваги та 1 бал за шкалою прагнення до досконалості; 
5) Картки нижнього щаблю - братик Іванко та сестричка Оленка - 0 балів за шкалою прагнення до переваги та 0 балів за шкалою прагнення до досконалості;

6) Усі інші персонажі нижнього щабля - 3 бали за шкалою прагнення до досконалості та 0 балів за шкалою прагнення до переваги.

2. Методика «Лабіринти» (автор - М.С. Курек, у модифікація методики Ф. Хоппе-М. Юкнат) [2]. Методика була спрямована на вивчення уявлення про рівень складності завдань, які може вирішити молодший школяр та його адекватності (реалістичності), що відображає здатність обирати цілі на основі реальної оцінки своїх можливостей і попередніх результатів діяльності.

Експериментальне завдання полягало у вільному послідовному виборі й вирішенні молодшим школярем завдань, ранжируваних за ступенем складності, i проводилось в індивідуальній формі. Стимульний матеріал методики складається $3 \quad 10$ лабіринтів, які різняться за ступенем складності. Застосовувалося 2 паралельні варіанти, що дозволяло учню за бажанням повторити вибір завдання вже відомого рівня складності.

Процедура проведення дослідження полягала в наступному. Перед досліджуваним двома паралельними рядками розкладалися картки розміром $12 \times 7$ см із написаними номерами завдань: від 1 до 10 у першому, від 1а до 10a у другому третьому рядках. Картки розташоваються в міру зростання складності, тобто номеру 1 відповідає найлегший лабіринт, а номеру 10 - найскладніший. Картки 3 другого рядку з однаковими номерами, наприклад 1a, містять у собі лабіринти однакового ступеня складності. Учню пропонується вибрати будь-яку картку відповідно до своїх можливостей, після чого треба буде знайти шлях від «входу» до «виходу» 3 лабіринту. Дослід припинявся або за бажанням молодшого школяра, або після 7 виборів.

У протоколі послідовно реєструвалися номери вибраних карток, результат виконання кожного завдання (успіх або невдача), особливості поведінки учня.

Адекватність домагань діагностувалася за наявністю типових-атипових виборів. Типовими визнавалися такі вибори, коли після успішного рішення вибиралося більш складне завдання, а після неуспішного - більш легке. Атиповими - такі вибори, які вказували на підйом домагань після невдачі й зниження їх після успіху.

У дослідженні визначалася зона складності, в якій переважно здійснювалися вибори. При визначенні зони складності виходили з того, що лабіринти 1-3 вважалися найбільш легкими, лабіринти 4-7 відповідали середньому, а 8-10 високому ступеню складності. Для кожного досліджуваного виділялася та зона складності, в якій зосереджувалася більшість виборів.

Адекватними (реалістичними) вважалися домагання, які характеризувалися відсутністю атипових кроків і виборами переважно в середній зоні складності.

Завищеними вважалися домагання, що характеризувалися наявністю 2 і більше випадків підвищення складності виборів після неуспішного виконання завдання й виборами переважно у високій зоні складності. 
Заниженими вважалися домагання, що характеризувалися наявністю 2 i більше випадків зниження складності виборів після успішного виконання завдання й виборами переважно в низькій зоні складності.

Інфантильними вважалися домагання, що характеризувалися неформуванням рівня домагань, коли успішність або неуспішність виконання попереднього завдання не впливала на складність вибору наступного.

3. Проєктивний казковий тест (The Fairy Tale Test - aвтор К. Колакоглоу) [1] спрямований на виявлення особистісних рис особистості дитини віком 7-12 років, а саме: амбівалентність, матеріальні потреби, бажання переваги, потреба у володінні речами (власності), домінантність, агресія типу А та типу Б, страх агресії, оральна агресія, потреби у допомозі. афіліації, прив'язаності, тривожність і депресія, значущість фігур матері та батька, сексуальна стурбованість та моральність, потреба у захисті та самооцінка.

Вибірку досліджуваних склали 204 молодших школяра, які навчалися у Харківській гімназії №169 м. Харкова у 3-4 класах протягом навчальних 20172018, 2018-2019 та 2019-2020 років.

У результаті впровадження кластерного аналізу методом К-середніх було отримано 5 кластерних профілів губристичної мотивації молодших школярів.

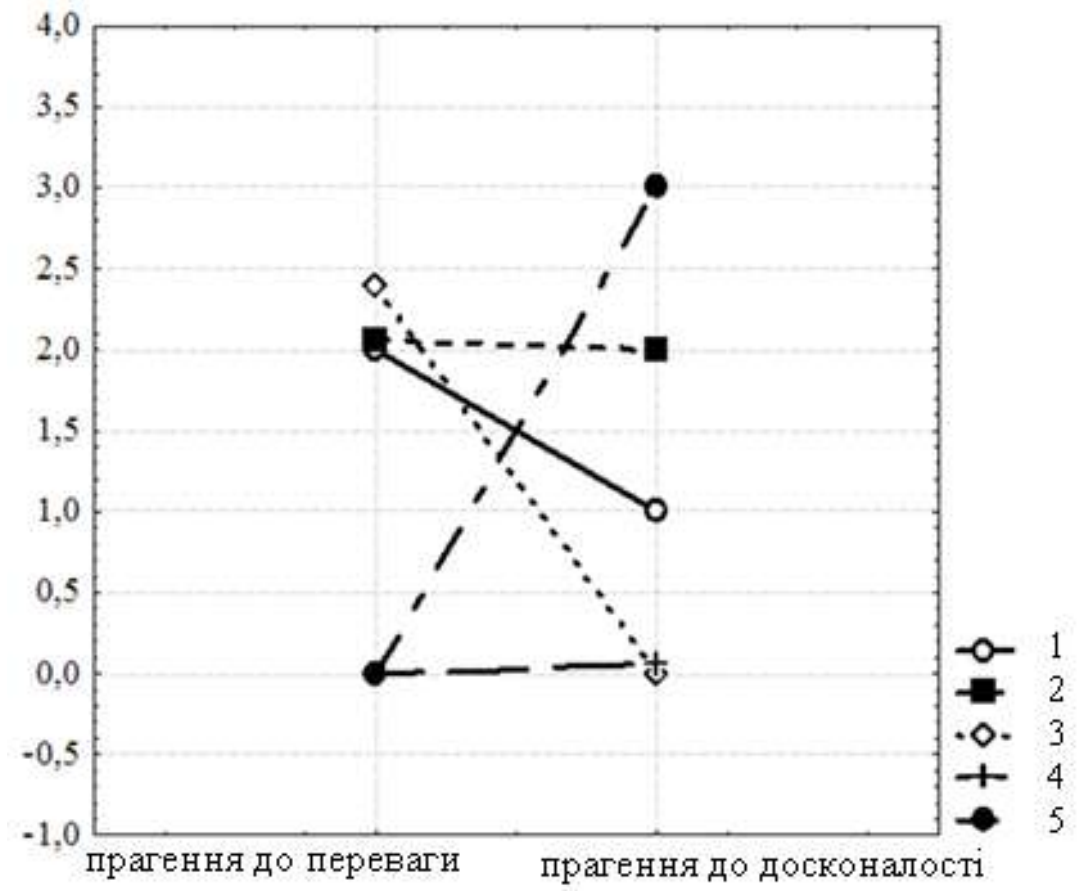

Рис. 1. Кластерні профілі губристичної мотиваиї̈ молодших школярів.

Кластер 1 утворений вищими за середні показниками прагнення до переваги та нижчими за середні показниками прагнення до досконалості «Помірне домінування прагнення до переваги».

Кластер 2 утворений вищими за середній рівень показниками прагнення до переваги та досконалості - «Збалансовані губристичні мотиви».

Кластер 3 представлений високими показниками прагнення до переваги та низьким рівнем прагнення до досконалості - «Домінування прагнення до переваги». 
Кластер 4 утворений низькими показниками губристичних мотивів «Низький рівень губристичної мотивації».

Кластер 5 представлений низьким рівнем прагнення до переваги та високим рівнем прагнення до досконалості - «Домінування прагнення до досконалості».

У таблиці 1 показано відмінності у прояві особистісних властивостей молодших школярів в залежності від типу губристичної мотивації.

Виявлено, що за схильністю до володіння матеріальними цінностями молодші школярів із «Домінуванням прагнення до досконалості» поступаються іншим школярам.

Молодші школярі із «Домінуванням прагнення до досконалості» мають найнижчий рівень прояву бажання переваги. Найвищий рівень цього прагнення виявлено у школярів із «збалансованими губристичними мотивами».

Ознаки домінантності більшою мірою властиві школярам із «Помірним домінуванням прагнення до переваги», а учнів із «Низьким рівнем губристичних мотивів» мають найнижчий рівень спрямованості на домінування над іншими.

В учнів як 3 «Домінуванням прагнення до досконалості» виявляється найвищий рівень агресії як захисту.

Таблиия 1

Особистісні властивості молодших школярів з різними типами губристичної мотивації

\begin{tabular}{|c|c|c|c|c|c|c|c|c|c|c|c|}
\hline \multirow{3}{*}{$\begin{array}{l}\text { Показники } \\
\text { особистісних } \\
\text { особливостей }\end{array}$} & & \multirow[t]{3}{*}{$\mathrm{F}$} \\
\hline & \multicolumn{2}{|c|}{ Кластер 1} & \multicolumn{2}{|c|}{ Кластер 2} & \multicolumn{2}{|c|}{ Кластер 3} & \multicolumn{2}{|c|}{ Кластер 4} & \multicolumn{2}{|c|}{ Кластер 5} & \\
\hline & $\mathrm{M}$ & $\sigma$ & $\mathrm{M}$ & $\sigma$ & $\mathrm{M}$ & $\sigma$ & $\mathrm{M}$ & $\sigma$ & $\mathrm{M}$ & $\sigma$ & \\
\hline Амбівалентність & 0,94 & 1,49 & 0,83 & 0,85 & 0,38 & 0,49 & 0,60 & 0,81 & 0,57 & 0,68 & 5,60 \\
\hline $\begin{array}{l}\text { Матеріальні } \\
\text { цінності }\end{array}$ & 0,89 & 1,21 & 0,78 & 1,05 & 0,61 & 0,96 & 0,90 & 1,75 & 0,25 & 0,44 & $2,78^{*}$ \\
\hline Перевага & 1,39 & 1,27 & 1,50 & 2,06 & 1,28 & 1,50 & 1,00 & 1,95 & 0,36 & 0,55 & $4,44 * *$ \\
\hline Власність & 0,67 & 0,83 & 0,39 & 0,77 & 0,44 & 0,84 & 0,60 & 0,81 & 0,54 & 0,95 & 0,63 \\
\hline Домінантність & 0,61 & 1,08 & 0,33 & 0,68 & 0,17 & 0,44 & 0,15 & 0,48 & 0,43 & 0,63 & $4,86^{* *}$ \\
\hline Агресія тип А & 0,94 & 1,80 & 0,72 & 1,26 & 0,94 & 1,18 & 0,65 & 1,17 & 0,68 & 0,86 & 0,51 \\
\hline $\begin{array}{l}\text { Агресія як } \\
\text { захист }\end{array}$ & 0,00 & 0,00 & 0,00 & 0,00 & 0,00 & 0,00 & 0,10 & 0,30 & 0,18 & 0,39 & $5,51 * * *$ \\
\hline Заздрість & 0,00 & 0,00 & 0,17 & 0,38 & 0,06 & 0,23 & 0,40 & 1,08 & 0,29 & 0,53 & $3,10^{*}$ \\
\hline $\begin{array}{l}\text { Агресія як } \\
\text { помста }\end{array}$ & 0,22 & 0,72 & 0,39 & 1,02 & 0,17 & 0,51 & 0,50 & 0,82 & 0,29 & 0,65 & 1,19 \\
\hline Страх агресії & 3,00 & 3,31 & 2,50 & 2,77 & 3,50 & 2,12 & 2,75 & 3,43 & 2,75 & 2,48 & 0,65 \\
\hline Оральна агресія & 1,39 & 1,36 & 1,28 & 1,65 & 1,06 & 1,37 & 1,10 & 1,86 & 1,50 & 1,39 & 0,66 \\
\hline Допомога & 1,28 & 1,61 & 1,83 & 2,42 & 0,71 & 1,43 & 1,45 & 3,01 & 1,04 & 1,41 & 1,57 \\
\hline Афіліація & 1,44 & 1,32 & 0,83 & 1,28 & 1,22 & 1,81 & 0,80 & 0,76 & 1,79 & 1,65 & $3,91 * *$ \\
\hline Тривожність & 2,18 & 1,75 & 1,56 & 1,83 & 2,61 & 2,22 & 1,65 & 1,58 & 1,54 & 1,51 & $2,78^{*}$ \\
\hline Депресія & 0,94 & 1,01 & 0,72 & 1,06 & 0,94 & 1,24 & 0,95 & 1,41 & 1,25 & 1,65 & 0,91 \\
\hline Матір & 0,56 & 2,37 & 1,33 & 2,83 & 0,22 & 1,77 & 1,80 & 2,78 & 1,68 & 1,69 & $3,67 * *$ \\
\hline Батько & 0,67 & 0,83 & 0,56 & 1,27 & 0,72 & 1,81 & 1,10 & 1,35 & 0,86 & 1,07 & 1,02 \\
\hline $\begin{array}{l}\text { Сексуальна } \\
\text { стурбованість }\end{array}$ & 1,61 & 1,44 & 2,50 & 2,91 & 1,28 & 1,50 & 1,45 & 1,41 & 1,14 & 1,26 & $3,64 * *$ \\
\hline Моральність & 0,89 & 1,12 & 0,61 & 0,96 & 0,33 & 1,17 & 0,35 & 0,66 & 0,71 & 1,20 & 1,97 \\
\hline Захист & 0,39 & 1,40 & 0,06 & 0,23 & 0,72 & 1,58 & 0,10 & 0,44 & 0,32 & 1,01 & 2,34 \\
\hline Самооцінка & 1,06 & 1,33 & 2,17 & 2,09 & 1,28 & 2,57 & 1,95 & 0,99 & 1,93 & 2,24 & 2,63 \\
\hline Прив'язаність & 1,28 & 1,30 & 1,61 & 2,39 & 2,56 & 3,84 & 1,85 & 2,68 & 1,75 & 2,80 & 1,09 \\
\hline
\end{tabular}


Афіліативне прагнення бути добрим другом і належати виражене найменше, натомість заздрість проявляється більшою мірою в учнів із «Низьким рівнем губристичної мотивації».

Тривожність більшою мірою характеризує молодших школярів iз «Домінуванням прагнення до переваги».

Фігура матері як значуща та загальна прив'язаність до матері $є$ більш вираженими у досліджуваних із «Низьким рівнем губристичної мотивації».

Сексуальна стурбованість більшою мірою виражена у школярів із «Збалансованими губристичними мотивами».

Моральність меншою мірою характеризує молодших школярів із «Домінуванням прагнення до переваги», натомість у школярів із «Помірним домінуванням прагнення до переваги» показники моральності $\epsilon$ найвищими.

Потреба у захисті та безпеці більшою мірою властива молодшим школярам із «Домінуванням прагнення до переваги».

Самооцінка $\epsilon$ найвищою в учнів із «Збалансованими губристичними мотивами».

Потреба у прив'язаності більшою мірою властиві молодшим школярам iз «Домінуванням прагнення до переваги».

У таблиці 2 показано особистісні особливості молодших школярів в залежності від рівня домагань.

Таблиия 2

Особистісні властивості молодших школярів з різним рівнем домагань

\begin{tabular}{|c|c|c|c|c|c|c|c|c|c|}
\hline \multirow{3}{*}{$\begin{array}{l}\text { Показники } \\
\text { особистісних } \\
\text { особливостей }\end{array}$} & \multicolumn{8}{|c|}{ Рівень домагань } & \multirow[t]{3}{*}{$\mathrm{F}$} \\
\hline & \multicolumn{2}{|c|}{ Занижений } & \multicolumn{2}{|c|}{ Адекватний } & \multicolumn{2}{|c|}{ Завищений } & \multicolumn{2}{|c|}{ Інфантильний } & \\
\hline & $\mathrm{M}$ & $\sigma$ & $\mathrm{M}$ & $\sigma$ & $\mathrm{M}$ & $\sigma$ & $\mathrm{M}$ & $\sigma$ & \\
\hline Амбівалентність & 1,09 & 1,75 & 0,56 & 0,71 & 0,72 & 0,93 & 0,63 & 0,65 & 1,32 \\
\hline $\begin{array}{l}\text { Матеріальні } \\
\text { цінності }\end{array}$ & 0,95 & 1,12 & 0,66 & 1,25 & 0,43 & 0,83 & 0,64 & 1,00 & 0,93 \\
\hline Перевага & 1,14 & 1,85 & 0,98 & 1,38 & 1,41 & 2,15 & 0,55 & 0,67 & 1,52 \\
\hline Власність & 0,76 & 1,26 & 0,49 & 0,76 & 0,57 & 1,01 & 0,45 & 0,51 & 0,68 \\
\hline Домінантність & 0,57 & 1,03 & 0,27 & 0,63 & 0,32 & 0,67 & 0,27 & 0,63 & 1,15 \\
\hline Агресія тип А & 1,24 & 2,07 & 0,57 & 1,00 & 0,81 & 1,27 & 1,36 & 1,18 & $3,83^{*}$ \\
\hline Агресія як захист & 0,10 & 0,30 & 0,05 & 0,22 & 0,11 & 0,31 & 0,09 & 0,29 & 0,69 \\
\hline Заздрість & 0,19 & 0,40 & 0,21 & 0,70 & 0,16 & 0,37 & 0,18 & 0,39 & 0,65 \\
\hline Агресія як помста & 0,48 & 0,93 & 0,27 & 0,73 & 0,27 & 0,56 & 0,45 & 1,01 & 0,72 \\
\hline Страх агресії & 2,43 & 1,86 & 3,20 & 3,09 & 2,54 & 2,55 & 2,09 & 2,37 & 1,46 \\
\hline Оральна агресія & 0,67 & 1,28 & 1,34 & 1,53 & 1,68 & 1,72 & 0,91 & 1,19 & 2,50 \\
\hline Допомога & 1,00 & 1,79 & 1,24 & 2,21 & 1,41 & 1,85 & 1,27 & 1,86 & 0,17 \\
\hline Афіліація & 1,10 & 1,51 & 1,47 & 1,63 & 0,68 & 0,82 & 1,27 & 0,98 & $2,96 *$ \\
\hline Тривожність & 1,81 & 2,16 & 2,06 & 1,89 & 1,27 & 1,35 & 1,82 & 1,37 & 1,85 \\
\hline Депресія & 0,76 & 1,18 & 1,04 & 1,42 & 0,95 & 1,43 & 1,00 & 0,87 & 0,27 \\
\hline Матір & $-0,48$ & 1,47 & 1,26 & 2,25 & 1,57 & 2,57 & 1,73 & 2,66 & $4,46 * *$ \\
\hline Батько & 1,10 & 1,22 & 0,57 & 1,01 & 1,14 & 1,36 & 1,18 & 2,17 & $3,23 *$ \\
\hline $\begin{array}{l}\text { Сексуальна } \\
\text { стурбованість }\end{array}$ & 0,95 & 1,66 & 0,60 & 0,96 & 0,32 & 0,78 & 0,64 & 1,26 & 2,59 \\
\hline Моральність & 0,86 & 1,82 & 0,34 & 1,10 & 0,00 & 0,00 & 0,18 & 0,59 & 1,61 \\
\hline Потреба у захисті & 0,62 & 2,01 & 1,89 & 1,78 & 1,97 & 2,28 & 1,27 & 2,19 & $3,09 *$ \\
\hline Самооцінка & 2,33 & 2,74 & 2,09 & 3,19 & 0,97 & 1,01 & 1,09 & 1,19 & $3,13^{*}$ \\
\hline Прив'язаність & 0,95 & 1,12 & 0,66 & 1,25 & 0,43 & 0,83 & 0,64 & 1,00 & 2,39 \\
\hline
\end{tabular}


Матеріальні цінності у школярів із заниженим рівнем домагань виражені найбільше, а із завищеним - найнижче. Отже, бажання отримувати іграшки, красиві речі та різні задоволення властиве молодшим школярам, які віддають перевагу надмірно легким завданням, натомість ті школярі, які віддають перевагу труднощам, як правило, нехтують матеріальними цінностями.

Бажання переваги як потреба досягнень та прагнення до змагань характеризує більшою мірою молодших школярів із завищеним рівнем домагань.

Прагнення володіти речами та контролювати власну території, іграшки та іншу власність, домінантність у стосунках властиві більшою мірою молодшим школярам із заниженим рівнем домагань.

Утім, означені вище особливості різняться не на статистично значущому рівні.

Агресія типу А як розвантаження агресивних фантазій та імпульсів властива учням із інфантильним рівнем домагань.

Агресія як захист меншою мірою властива школярам із адекватним рівнем домагань, хоча і не на статистично значущому рівні.

За показниками заздрості, агресії як помсти, оральної агресії та страху агресії відмінностей не виявлено. Прагнення допомоги також не залежить від рівня домагань.

Афіліативна вмотивованість меншою мірою характеризує молодших школярів із завищеним рівнем домагань.

Тривожність та депресія не залежать від рівня домагань школярів.

Фігура матері $\epsilon$ найбільш значущою для молодших школярів 3 інфантильним рівнем домагань, а в учнів із заниженим рівнем домагань відбулась сепарація з матірю.

Фігура батька є менш значущою для молодших школярів із адекватним рівнем домагань.

Сексуальна стурбованість та моральність не залежать від рівня домагань молодших школярів.

Потреба у захисті як прагнення до безпеки та отримання допомоги від більш сильних, меншою мірою властива молодшим школярам із заниженим рівнем домагань, а найбільше - із завищеним.

Найнижча самооцінка характеризує молодших школярів із завищеним рівнем домагань.

Потреба у прив'язаності більшою мірою характеризує молодших школярів із заниженим рівнем домагань.

Наступним завданням було виявлення ролі рівня домагань та типу губристичної мотивації як двох пов'язаних факторів у становленні особистісних властивостей молодших школярів.

На рис. 1 показано відмінності у показниках амбівалентності в залежності від рівня домагань та типу губристичної мотивації. 


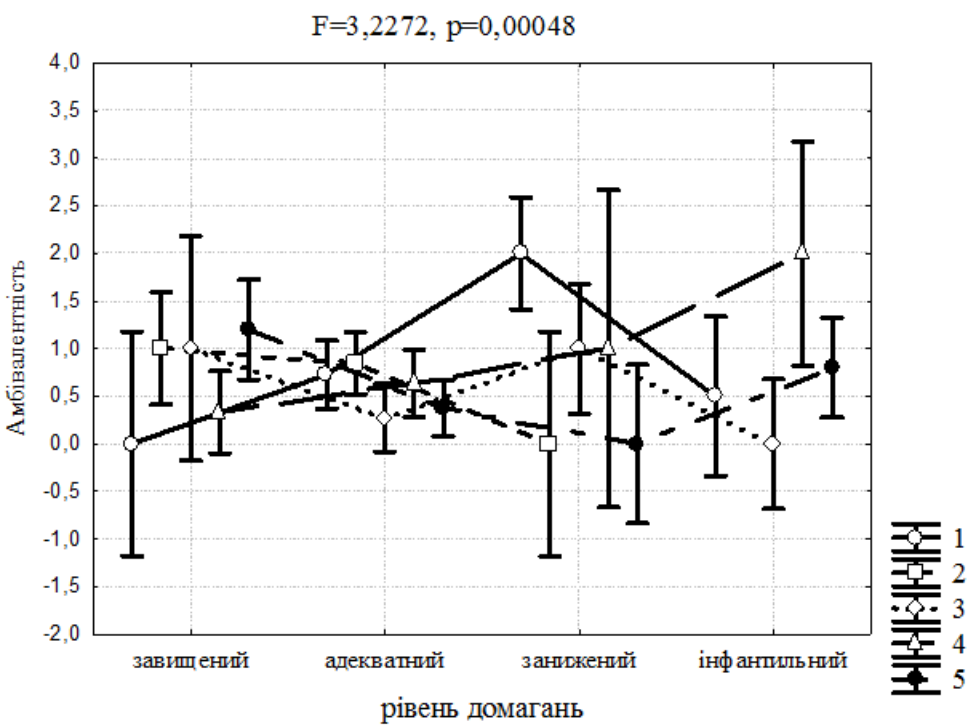

Рис. 3. Амбівалентність молодших школярів в залежності від рівня домагань та типу губристичної мотиваџії.

Занижений рівень домагань та помірне домінування губристичного прагнення до переваги у молодших школярів пов'язане із найвищими показниками амбівалентності як здатності інтегрувати два образи матері поганої та доброї, що проявляється у бажанні автономності та індивідуальності, з одного боку, та залежністю від матері, або особи що їі заміщує - з іншої.

На рис. 2 показано, що досліджувані із завищеним рівнем домагань та помірним домінуванням прагнення до переваги мають найвищі показники домінування. Занижений рівень домагань у школярів 3 помірним домінуванням прагнення до переваги також позитивно позначається на схильності до домінування молодших школярів.

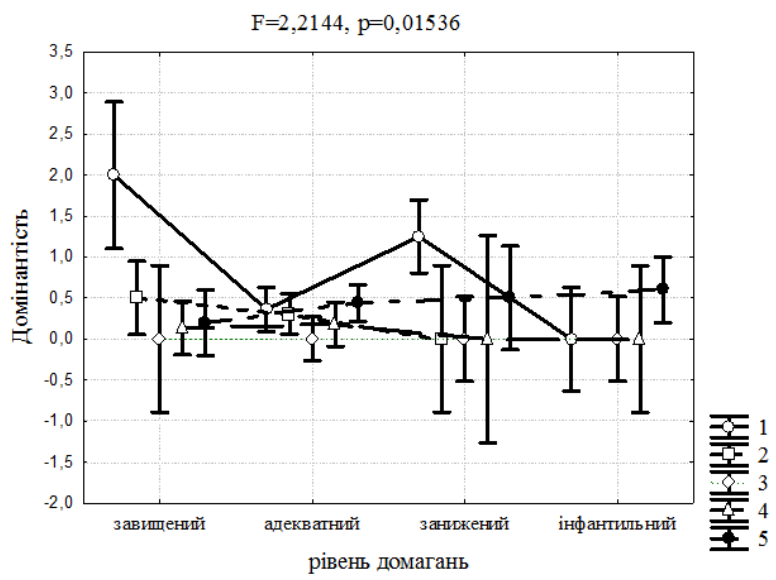

Pис. 3. Домінантність молодших школярів в залежності від рівня домагань та типу губристичної мотивації.

Інфантильний рівень домагань на тлі помірного домінування прагнення до переваги зумовлює найвищі показники агресії типу А у молодших школярів (рис. 2). 


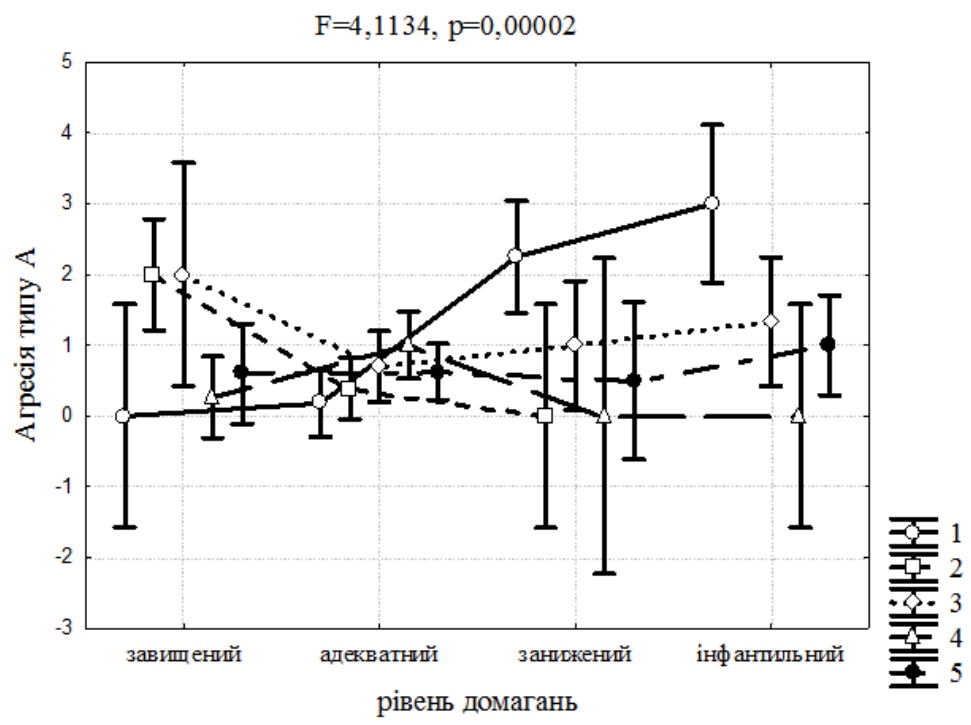

Pис. 3. Агресія типу А молодших школярів в залежності від рівня домагань та типу губристичної мотивації.

Домінування прагнення до досконалості на тлі заниженого рівня домагань пов'язана із агресією як помстою у молодших школярів. Низький рівень губристичної мотивації разом із інфантильним рівнем домагань зумовлюють найвищий рівень агресії як помсти.

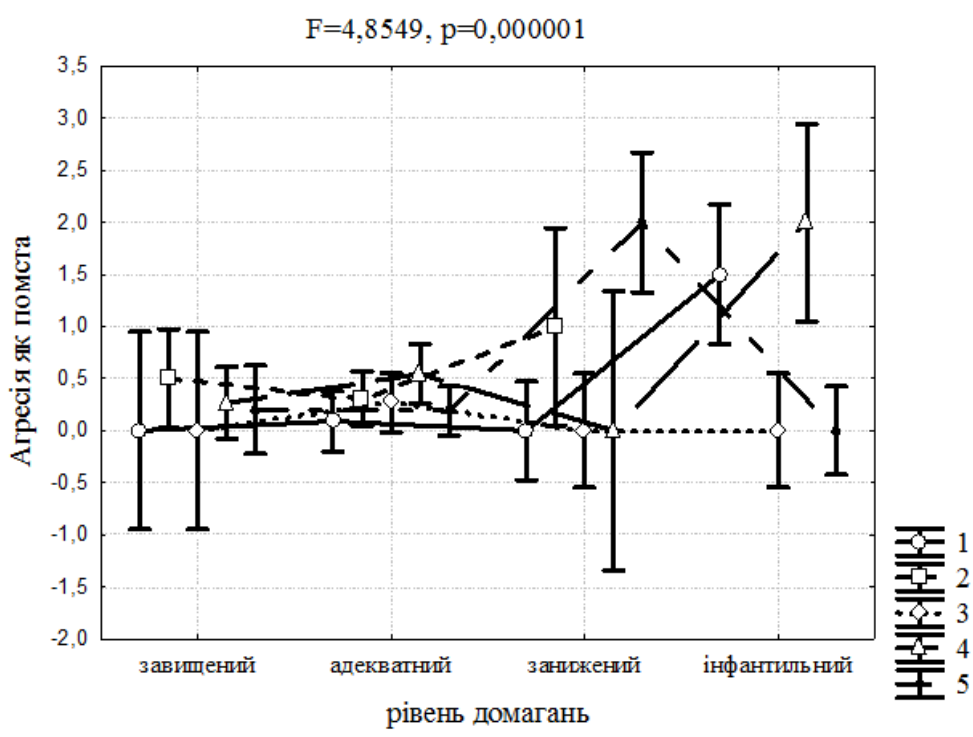

Puc. 4. Агресія як помста молодших школярів в залежності від рівня домагань та типу губристичної мотивації.

Фігура батька $є$ найбільш значущою для молодших школярів із заниженим рівнем домагань та домінуванням прагнення до досконалості (рис.5). 


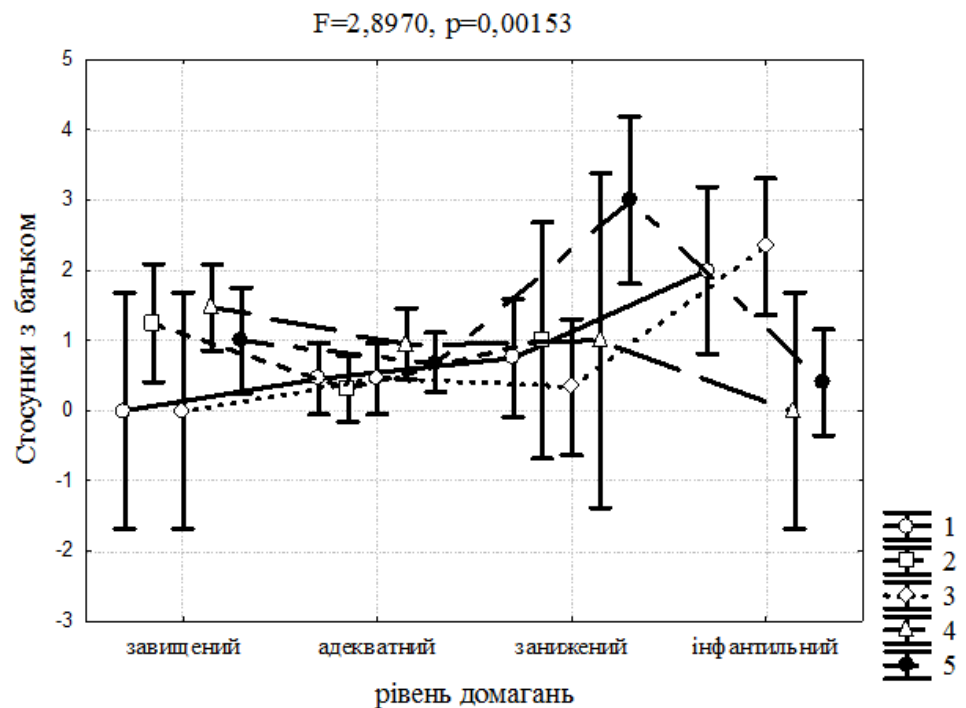

Puс. 5. Стосунки за батьком молодших школярів в залежності від рівня домагань та типу губристичної мотивачії.

Завищений рівень домагань на тлі помірного домінування прагнення до переваги зумовлює найвищий рівень прояву бажання переваги, так само як $\mathrm{i}$ збалансовані губристичні мотиви разом із завищеним рівнем домагань.

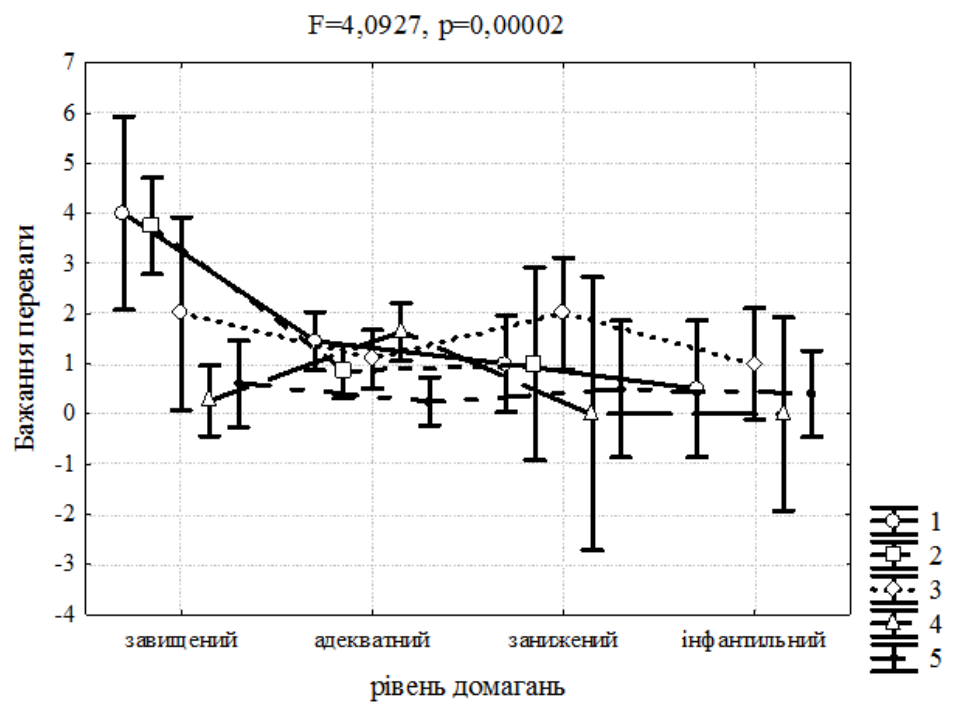

Pис. 6. Бажання переваги молодших школярів в залежності від рівня домагань та типу губристичної мотивації.

Сексуальна стурбованість властива більшою мірою молодшим школярам із завищеним рівнем домагань на тлі збалансованої губристичної мотивації (рис. 7). 


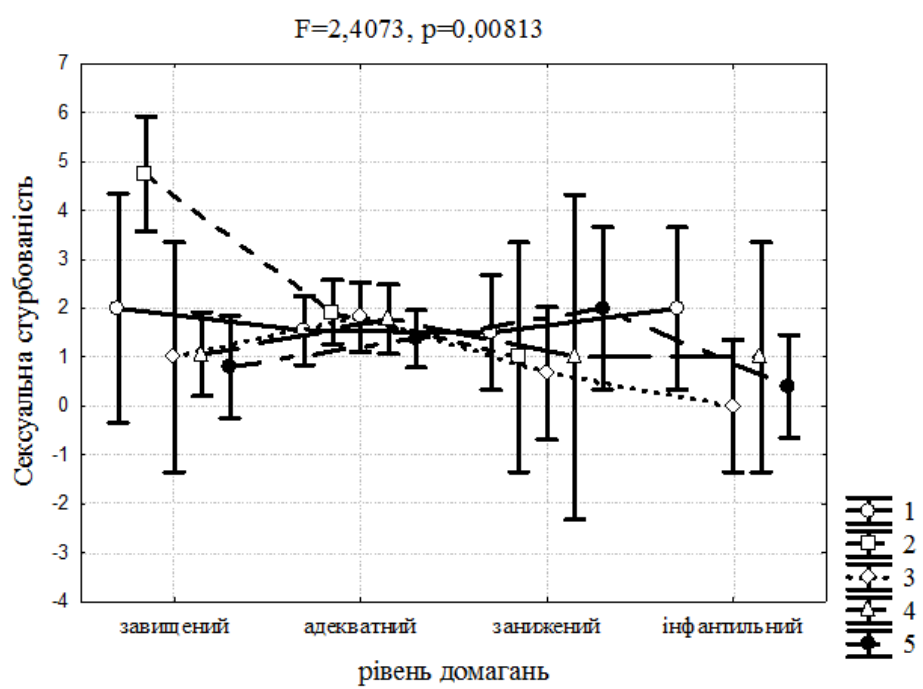

Pис. 7. Сексуальна стурбованість молодших школярів в залежності від рівня домагань та типу губристичної мотивації.

Завищений рівень домагань разом із помірним домінуванням прагнення до переваги зумовлюють найвищі показники моральності у молодших школярів (рис. 8).

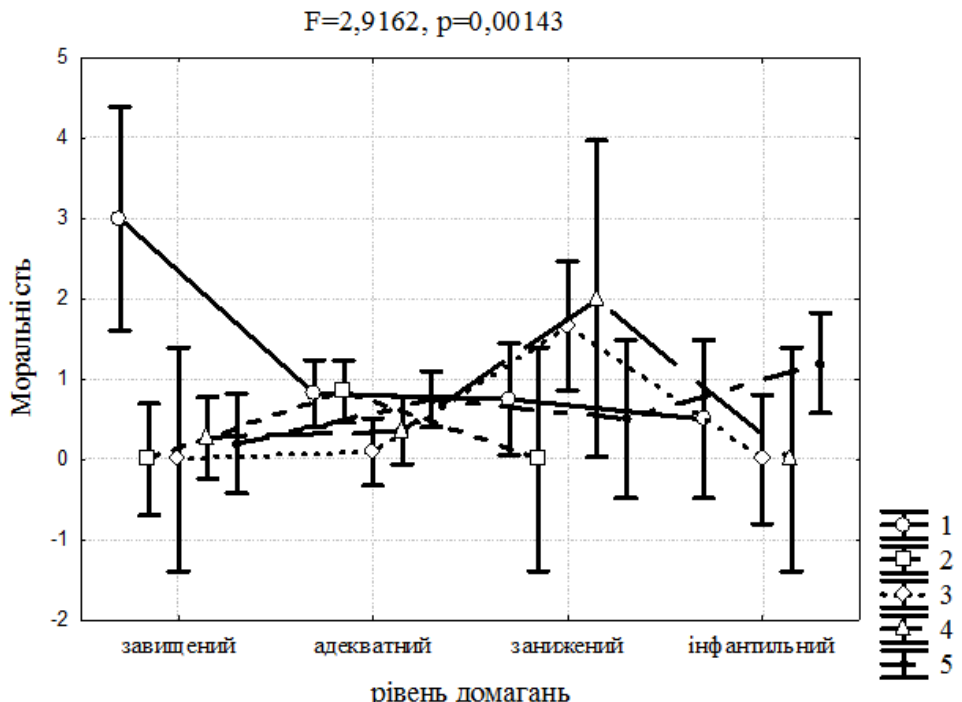

Puс. 8. Моральність молодших школярів в залежності від рівня домагань та типу губристичної мотиваџії.

Отже, тип губристичної мотивації та рівень домагань є важливими факторами у розвитку особистісних особливостей молодших школярів.

Висновки. Дослідження губристичних мотивів молодших школярів $\epsilon$ актуальним напрямом наукових розвідок, особливо в контексті аналізу особистісного розвитку учнів під впливом губристичної мотивації та рівня домагань.

Емпірично виявлено специфіку особистісних властивостей молодших школярів з різним типами губристичної мотивації. За рівнем схильності до 
володіння матеріальними цінностями та бажанням переваги молодші школярів із «Домінуванням прагнення до досконалості» поступаються іншим школярам, утім вони переважають інших за показниками агресії як захисту. Ознаки домінантності більшою мірою властиві школярам із «Помірним домінуванням прагнення до переваги», а учнів із «Низьким рівнем губристичних мотивів» мають найнижчий рівень спрямованості на домінування над іншими. Афіліативне прагнення бути добрим другом і належати виражене найменше, натомість заздрість проявляється більшою мірою в учнів із «Низьким рівнем губристичної мотивації». Тривожність більшою мірою характеризує молодших школярів із «Домінуванням прагнення до переваги». Фігура матері як значуща та загальна прив'язаність до матері є більш вираженими у досліджуваних із «Низьким рівнем губристичної мотивації». Сексуальна стурбованість та самооцінка більшою мірою виражені у школярів із «Збалансованими губристичними мотивами». Моральність меншою мірою, а потреба у захисті та у прив'язаності - більшою мірою характеризує молодших школярів із «Домінуванням прагнення до переваги».

Виявлено рівномірну представленість молодших школярів 3 рівнем домагань - завищеним, заниженим, адекватним та інфантильним. Показано, статистично значущі відмінності для учнів з різним рівнем домагань виявлено за параметрами агресії типу А, потреби в афіліації та захисті, значущості фігур матері та батька, а також самооцінки.

Визначено, що тип губристичної мотивації разом 3 рівнем домагань позначаються на рівні розвитку амбівалентності, домінування, агресії типу А, агресії як помсти, значущості фігури батька, бажання переваги, сексуальної стурбованості та моральності у молодших школярів.

\section{Лimepamypa:}

1. Колакоглоу К. (2003). Проективный сказочный тест: Руководство к применению / Пер. и адаптация Е.А. Савиной. М.: Когито-Центр.

2. Худик, В.А. (1992). Психологическая диагностика детского развития: методы исследования. К., Освіта.

3. Фоменко, К.І. (2017). Психодіагностика мотиваційної сфери молодшого школяра. Вісник ХНПУ імені Г.С. Сковороди. Психологія. Вип. 55. Х.: ХНПУ, 280-295.

4. Fomenko K., Nadyon V., Diomidova N., Shukalova O. Hubristic motivation as a factor of the primary school's pupils' personal development. Вісник ХНПУ імені Г.С. Сковороди. Психологія. Вип. 61. Х.: ХНПУ, 150-168. doi.org/10.34142/23129387.2019.61.09

\section{References:}

1. Kolakohlou K. (2003). Proektyvnyy skazochnyy test: Rukovodstvo $k$ prymenenyyu [Projective Fairy Test: Guide to Application] / Per. y adaptatsyya E.A. Savynoy. M.: KohytoTsentr. [in Russian].

2. Khudyk, V.A. (1992). [Psykholohycheskaya dyahnostyka det.skoho razvytyya: metody yssledovanyya - Psychological diagnosis of child development: research methods]. K., Osvita. [in Russian].

3. Fomenko, K.I. (2017). Psykhodiahnostyka motyvatsiynoyi sfery molodshoho shkolyara 
[Psychodiagnostics of the motivational sphere of a junior student.]. Visnyk KHNPU imeni H.S. Skovorody. Psykholohiya - Bulletin of KhNPU named H.S. Skovoroda. Psychology, 55, 280-295. KH.: KHNPU [in Ukrainian].

4. Fomenko K., Nadyon V., Diomidova N., Shukalova O. Hubristic motivation as a factor of the primary school's pupils' personal development. Visnyk KHNPU imeni H.S. Skovorody. Psykholohiya - Bulletin of KhNPU named H.S. Skovoroda. Psychology, 61, 150-168 KH.: KHNPU doi.org/10.34142/23129387.2019.61.09 